\title{
И.В. КУТЫКОВА
}

\section{О СООТНОШЕНИИ ПОНЯТИЙ "ИСТОРИЧЕСКАЯ КУЛЬТУРА» И «ИСТОРИЧЕСКОЕ СОЗНАНИЕ»}

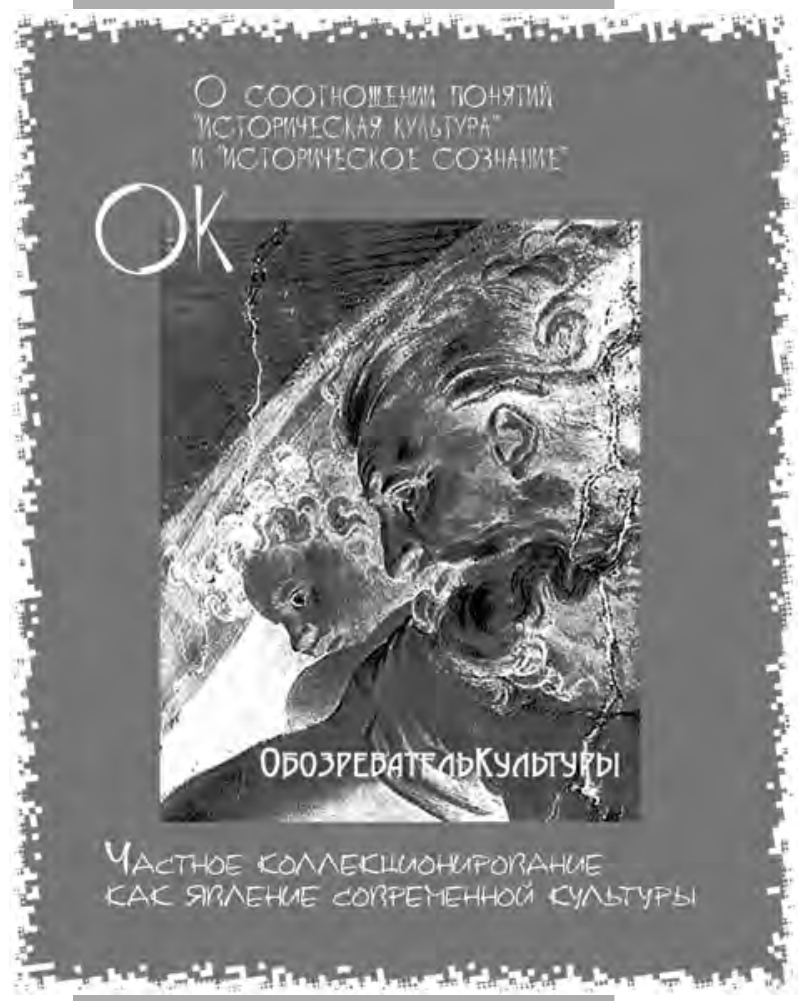

Рассматриваются основные понятия, раскрывающие содержание исторического духовного бытия. Вопрос соотношения понятий «историческое сознание» и «историческая культура» раскрывается на основании анализа современных подходов к пониманию исторического сознания и исторической культуры, а также подходов к пониманию культуры. Понятие «историческое сознание» представлено в нескольких значениях. Понятие исторической культуры рассматривается в контексте типологического культурного многообразия.

Ключевые слова: историческое духовное бытие, культура, историческое сознание, историческая культура, философия истории, современность.

И

сторическое духовное бытие раскрывается, как правило, через понятия «историческое сознание», «историческая культура», «философско-историческое мировоззрение». Если понятие «философия истории» выражает философский взгляд, обращенный на историю и место человека в ней, то понятия «историческое сознание» и «историческая культура» аккумулируют в себе многообразие взглядов исторических субъектов на историю и «историческое» на различных уровнях человеческого бытия (теоретическом и практическом, рациональном и иррациональном, повседневности и вечности), в различных формах. При этом понятие «историческое сознание» объемлет в себе философско-исторический взгляд на историю, а понятие «историческая культура» раскрывает теоретико-практический путь воплощения содержания исторического сознания в исторической по-

\section{НАСЛЕДИЕ}


вседневности. Система взглядов на историю и место в ней человека - философия истории. Система отношений «история и исторический субъект» в определенный интервал исторического времени и пространства раскрывается через понятия «историческое сознание»и «историческая культура».

Понятие «культура» является одним из ключевых понятий, входящих в индивидуальное и общественное сознание, но свое, особенно актуальное значение оно приобретает во время исторического перелома. При этом от потребности понимания, как явной, так и неявной, до использования понятия и, главное, реализации в современной действительности смысла, заключенного в нем, зачастую дистанция огромного размера. Ее существование следует связать с низкой степенью интериоризации сущности культуры, заключенной в понятии, главным образом, на повседневном уровне. Овладение понятием «культура» носит зачастую поверхностный и проблемный характер. В качестве его проявления следует назвать актуальные проблемы, принадлежащие экологии культуры, например, экологии языка и речи.

Выявляемое в науке культурное типологическое многообразие, например: правовая, политическая, повседневная, традиционная, массовая культура - в последние десятилетия расширилось за счет понятия «историческая культура». Наиболее активно исследование исторической культуры проводится западноевропейскими учеными (Б. Гене, Е.А. Нуттунен) [1; 2]. В отечественной науке историческая культура как предмет исследования находится в центре внимания Л.П. Репиной; к явлению и понятию новой исторической культуры, к вопросу о связи исторической культуры и идентичности обращается В.А. Тишков [3-6].

Под исторической культурой понимают, например, историческое общество, историческую память и образы прошлого в культуре, историческую реконструкцию, исторические памятники и музеи. Историческая культура, по Е.А. Нуттунен, есть отбор фактов в соответствии с определенными ценностями [2, с. 44]. Появление исторической культуры как предмета исследования, согласно Л.П. Репиной, связано с изучением исторических представлений о прошлом. В изучении исторической культуры, подчеркивает В.А. Тишков, наиболее важными оказываются исторические мифы, ментальные стереотипы, обыденное историческое сознание, историческая память. Новая историческая культура характеризуется большей вовлеченностью массовой публики в исторические сюжеты, от истории рода и семьи до древних эпох и начала человеческой истории [4, с. 9, 11]. Категория «историческая культура», как отмечает М.С. Бобкова, «включает в себя многоуровневый процесс формирования в обществе представлений о своем прошлом, реконструкцию образа прошлого, которая предопределяется социальной актуализацией исторических событий и их осмыслением в рамках заданной во времени и пространстве современности идеологической и культурной парадигмой» [3, с. 455].

Новое и столь необходимое сегодня понятие «историческая культура» нуждается в рефлексии и, как представляется, в контексте соотношения с другими поняти- ями, используемыми для характеристики совокупности взаимоотношений человека и истории, прежде всего с понятием «историческое сознание».

В широком смысле под исторической культурой (или культурой истории) следует понимать отношение исторического субъекта (человека, общества, человечества) к истории во всех ее значениях, а также распространение и транслирование «исторического», в том числе в современной повседневной действительности. В узком смысле - историческая культура представляет собой многоуровневое и многоаспектное понятие, специфическое явление, актуальную проблему.

Содержательно историческая культура включает в себя: пропаганду исторических ценностей, идеалов и смыслов, формирующих позитивное отношение к прошлому; организацию (игровой, познавательной, трудовой, творческой) деятельности на теоретическом и практическом уровне, направленную на формирование представлений современника об историческом прошлом; историческое воспитание и образование; исторические традиции; историческое наследие.

Формами исторической культуры являются исторические реконструкции, костюмы, музеи, традиции, исторические памятники. Уровни исторической культуры: теоретический и практический; бытовой и профессиональный; индивидуальный и массовый. Носителями исторической культуры выступают личность, социальные общности (этнические, социально-классовые, социально-профессиональные), социально-демографические группы, человечество.

Что заключает в себе понятие «историческое сознание»? Историческое сознание, прежде всего, есть одно из центральных понятий социальной философии и философии истории, кроме того, с начала XXI века - исторической науки, исторической психологии и социологии. В условиях социально-исторических реалий конца XX — начала XXI века тема исторического сознания актуализируется в качестве социокультурной и мировоззренческой проблемы современности, сохраняя статус научной проблемы, утвердившийся в отечественной философии к 1970-м годам.

В 2000-е годы проблема исторического сознания рассматривается в гносеологическом, социокультурном аспектах, в контексте человеческого бытия, современных глобализационных процессов, трансформации российского общества. Историческое сознание ныне понимается как явление духовной культуры, при этом конкретизируется его роль в социокультурном процессе, выделяются некоторые особенности исторического сознания русского народа и его влияние на историческое развитие России; формулируется точка зрения, согласно которой история предстает как тип сознания, а историческим сознанием определяется настоящее и будущее положение человечества, политическая социализация молодежи; в качестве источника формирования исторического сознания признается художественная литература; рассматривается вопрос об особенностях массового исторического сознания, его мифологизации [7-11]. Традиционно исследуются структура, уровни и функции исторического сознания, сущность исторического мышления, принцип историзма [12-16]. 
Новацией в научной разработке темы исторического сознания в 2000-е годы стало издание учебных пособий, а также появление специальных глав в курсах авторских лекций. Рассмотрение вопроса исторического сознания и его компонентов стало неотъемлемой частью философского анализа и социологического исследования проблем социализации молодежи, в частности студенческой. Уделяется внимание адаптационным возможностям молодежи в современном российском обществе, патриотическому воспитанию, историческому знанию; анализируется формирование исторического сознания школьной и студенческой молодежи, состояние, функционирование исторического сознания первого постсоветского поколения [17-22]. Гносеологические аспекты исторического сознания главным образом рассматриваются в контексте профессиональной исследовательской деятельности историка, выработки концепции учебника по истории для учащейся и студенческой молодежи, осмысления значения исторического знания в современном российском обществе [23-27].

Научное исследование проблемы исторического сознания в начале XXI века выходит далеко за пределы компетенции какой-либо формы культуры и предусматривает реализацию целостного подхода к исследованию исторического сознания, как вследствие его структурной целостности [28], так и социально-антропологического смысла исторического сознания.

Анализ современной научной литературы (19902000-е годы), посвященной исследованию исторического сознания, позволяет в самом общем виде выделить наиболее типичные подходы к его пониманию.

В рамках феноменологического подхода историческое сознание рассматривается как:

- феномен, явление духовной культуры;

- срез общественного сознания;

- духовная сторона исторического процесса, представляющая собой отражение, познание, осмысление, интерпретацию, вынесение оценок, выражение эмоций, постижение человеческой истории как процесса, протекающего во времени, в единстве настоящего, прошлого и будущего [29, с. 10].

Историческое сознание в качестве феномена осмысливается в понятиях «смысл истории», «русская идея» и др., как особого рода духовная реальность [30, с. 12], как многогранное явление духовной сферы, отражение прошлого в общественном сознании и временной срез всех форм общественного сознания, один из факторов социальной стабильности [31, с. 10, 35].

Для сторонников феноменологического подхода историческое сознание - это проявление общественного сознания, важная составляющая духовной культуры общества, сложное, многогранное духовно-практическое образование [32], один из феноменов социокультурной регуляции поведения индивидов и коллективов, социальных групп и сословий, этносов и общества в целом $[32$, с. 9,10$]$.

Приверженцы структурного подхода изучают историческое сознание как один из компонентов общественного сознания [30; 33] наряду с религией, искусством, экономикой. «Обеспечивая» связь человеческой истории, историческое сознание выступает существенно важным элементом общественной жизни, необходимой предпосылкой самой истории» [30, с. 30]. Историческое сознание - чувство истории - «это то, что позволяет нам воспроизводить события как историю, традицию, в которой в какой-то точке включены и мы» [34, с. 119]. Историческое сознание тождественно историческому знанию [35, с. 17].

Сущностный (целостный) подход основан на рассмотрении исторического сознания как относительно самостоятельной формы общественного сознания, целостной системы, вызванной к жизни реальными потребностями обеспечения связи времен, преемственности поколений, передачи социального опыта, изучения и осмысления прошлого (необходимого для понимания настоящего и прогнозирования будущего). Критерии зрелости исторического сознания - это понимание исторического прошлого, критическое и творческое усвоение его уроков широкими массами и политическими, государственными лидерами [36, с. 2, 14].

Осмысление исторического сознания в условиях социокультурной трансформации сопряжено, кроме прочего, с его практическим «выходом» в пространство повседневной реальности. Понятие «историческое сознание» может быть рассмотрено в нескольких значениях.

1. Историческое сознание как специфическое целостное духовное образование, являющееся выражением сути исторического бытия, или историчности человека и общества от микро- до макроуровня истории в их взаимодействии и ретроперспективе. Наряду с экологическим сознанием историческое сознание способно предстать в качестве императива современности, фундаментального духовного основания переломной эпохи в период преодоления последствий перелома.

2. Историческое сознание как самостоятельный тuп сознания с присущей ему структурой, содержанием, назначением, объемлющим на разных уровнях его организации совокупность исторических чувств, образов, интересов, воспоминаний, представлений, знаний, значений и смыслов истории. Его носителями выступают человек, социальные группы и общности, человечество. Историческая память есть фундаментальный компонент исторического сознания, с которым связано, собственно, хранение исторических образов и понятий, их воспроизводство посредством трансляции, а также высвобождаемых воспоминаний об исторических событиях, фактах, лицах в условиях современной социальной и повседневной действительности. Историческая память представляет собой скрепу культурно-исторической идентичности и основание исторической дальнозоркости для субъектов исторической реальности.

3. Историческое сознание как принцип общественного развития периода трансформации. Рассмотрение исторического сознания в качестве принципа общественного развития представляется возможным в связи с тем, что формирование и функционирование исторического сознания в повседневности способствует утверждению сдерживающего и сберегающего в самом положительном значении консервативного начала в жизни современника, 
в том числе в стремительно изменяющихся, модернизирующихся условиях человеческого бытия.

4. Историческое сознание как философско-историческая и социогуманитарная проблема.

Проблемный характер исторического сознания имеет несколько аспектов:

- мировоззренческий (ценности, убеждения и принципы в системе отношений «современник-история»);

- гносеологический и методологический (содержание, или компоненты исторического сознания, методы его познания);

- социально-философский и философско-исторический, социолого-исторический (состояние и функционирование исторического сознания современника, его динамика, место, роль в жизни современного общества, смысл исторического сознания), психолого-исторический;

- философско-антропологический (явления и сущность историчности человека, историческое сознание и сущность человека);

- культурологический (историческая культура);

- этический (морально-нравственные принципы бытия человека как исторического существа).

Формирование и функционирование исторического сознания связаны с исторической культурой, представляющей собой компонент исторического сознания. Понятие «историческое сознание» содержательно шире понятия исторической культуры.

В многообразии наиболее характерных определений культуры, систематизированных М.С. Каганом в работе «Философия культуры», следует выделить определение культуры, предложенное Э.С. Маркаряном [37, с. 15-17]. Культура, согласно Э.С. Маркаряну, «означает специфический, наиболее высокий по своим потенциальным возможностям способ деятельности (курсив мой. - И.К.) живых существ и организации их коллективной жизни, способ, обеспечивающий, с одной стороны, соединение элементов системы в упорядоченное, координированно действующее целое, а с другой, упорядоченное взаимодействие системы со средой». Суть культуры состоит в выработке живыми существами внебиологических средств и механизмов, позволяющих контролировать общую биологическую природу индивидов, составляющих общество, программировать и направлять их поведение «в требуемом для поддержания социальной жизни русле», обеспечивать специфический обмен веществ между социальной системой и природой. Культура как способ деятельности «позволяет действовать в окружающем мире, целенаправленно изменяя его, и адаптироваться к нему» [38, с. 6-7]. Культура «как специфический способ деятельности людей (специфический способ их существования)» предусматривает понимание соответствующих средств и механизмов, а также умение ими оперировать. Культура представляет собой тот самый способ, «благодаря которому направляется и осуществляется человеческая активность». «Культурные механизмы находят свою реализацию в процессах деятельности людей, которые и выступают в качестве непосредственных средств решения, стоящих перед людьми задач, в ходе реального функционирования и развития их социальной жизни» [38, с. 7-8]. Характеристика исторически данной культуры (исторических культур) сопряжена со специфическими чертами способов существования, выработанных различными народами [38, с. 25].

Данный подход к пониманию культуры в контексте осмысления соотношения понятий «историческая культура» и «историческое сознание» представляется наиболее подходящим для уточнения их познавательного статуса. В этой связи под исторической культурой следует понимать средства и механизмы регуляции социальных отношений в историческом контексте, сферу культуры. Большое познавательное и мировоззренческое значение имеет изучение исторической культуры периодов и эпох, стран и народов (всеобщий и локальный аспект). По отношению к понятию «историческое сознание» историческая культура предстает в качестве его конструкта. Историческая культура средство и механизм формирования и функционирования исторического сознания. Состояние исторической культуры в историческом настоящем (современности) являет собой, с одной стороны, индикатор проблем исторического сознания, а с другой - средство их преодоления.

Таким образом, сравнительная характеристика понятий «историческая культура» и «историческое сознание» позволяет акцентировать внимание на следующих положениях:

- структуру и содержание исторического сознания составляют интересы, потребности, предпочтения, воспоминания, предвидения, идеалы, взгляды, знания, оценки, теории, идеи, чувства, образы, символы, а также предания, легенды и мифы, анекдоты и песни, связанные с «историческим» (процессом, периодом, эпохой, фактом, событием, явлением, лицом).

- историческая культура включает в себя пропаганду исторических ценностей, идеалов и смыслов, формирующих позитивное отношение к прошлому; организацию игровой, познавательной, трудовой, творческой деятельности на теоретическом и практическом уровне, направленную на формирование представлений современника об историческом прошлом, сохранение и выработку исторических ценностей в историческом настоящем; историческое воспитание и образование; исторические традиции и историческое наследие.

- историческая культура предстает в таких формах, как исторические реконструкции, костюмы, музеи, традиции, исторические памятники и др. Формы исторического сознания - это исторические знания, философско-исторические взгляды, оценки, ценностные ориентиры, смыслы и значения, результаты социолого-исторического, психолого-исторического познания и художественного освоения «исторического» (исторический жанр живописи, исторический роман); предания, мифы, легенды, анекдоты, песни.

- уровни исторической культуры и исторического сознания: теоретический и практический; индивидуальный и коллективный; профессиональный и бытовой (повседневный). Носители исторической культуры 
и исторического сознания: человек (индивид, личность), социальные общности, социальные группы, человечество.

В историческом сознании совмещены три модуса времени: прошлое, настоящее и будущее. Принцип исторического сознания - преемственность поколений. В исторической культуре внимание акцентируется на историческом прошлом и настоящем, например, современная историческая культура, историческая культура XVIII века и т. д. Принцип исторической культуры - сохранение.

С исторической культурой связаны процессы формирования и функционирования исторического сознания. Историческая культура есть практико-повседневный компонент исторического сознания. Понятие «историческое сознание» содержательно шире понятия «историческая культура». Культурологический аспект проблемы исторического сознания заключен в исторической культуре. Историческая культура предполагает, собственно, отношение к истории, распространение и транслирование «исторического» в современной повседневности, а также деятельность, направленную на выработку принципов отношения к истории.

Под исторической культурой следует понимать средства и механизмы регуляции социальных отношений в историческом контексте, сферу культуры. По отношению к понятию «историческое сознание» историческая культура предстает в качестве его конструкта. Историческая культура есть средство и механизм формирования исторического сознания.

Мир ценностей исторической культуры, объединяющей в себе духовные и материальные ценности многочисленных поколений в историческом пространственно-временном континууме, представляет собой один из ценностных миров современного человека. Актуальное состояние данного ценностного мира и его воплощение на обыденно-практическом, повседневном уровне носят проблемный характер.

Деструктурированное, рассогласованное состояние сознания эпохи глобальной трансформации содержит потенциальную и актуальную потребность субъекта истории в преодолении конфронтации «исторического прошлого и исторического настоящего», «глобально-исторического и локально-исторического», «младости и старости». Модернизация общества, в том числе духовно-нравственная, может и должна быть связана с историзацией, иначе говоря, с развитием исторического сознания и исторической культуры.

\section{Список литературы}

1. Гене Б. История и историческая культура средневекового Запада. - М.: Языки славянской культуры, 2001.

2. Нуттунен Е.А. Музей в системе формирования исторической культуры // Человек и образование. - 2011. - № 3(28).

3. История и память: историческая культура Европы до начала Нового времени. - М.: Кругъ, 2006.

4. Тишков В.А. Историческая культура и идентичность // Уральский исторический вестник. - 2011. - № 2 (31).

5. Тишков В.А. Новая историческая культура. - М.: Изд-во Московского психолого-социального института, 2011.
6. Историческая культура императорской России: формирование представлений о прошлом. - М.: Изд. дом Высшей школы экономики, 2012.

7. Малькова Л.Ю. Современность как история: Реализация мифа в отечественной кинодокументалистике: автореф. дис. ... д-ра искусствоведения. - М., 2001.

8. Свирида Н.Н. Историческое сознание как явление культуры: автореф. дис. ... канд. филос. наук. - Омск, 2004.

9. Мильдон В.И. История и утопия как типы сознания // Вопросы философии. - 2006. - № 1.

10. Лыскова М.И. Художественная литература как источник формирования массового исторического сознания: социально-философский анализ. - Тюмень, 2007.

11. Миронов А.Н. Истинной истории истоки, или История как достоверный прообраз настоящего и будущего. - СПб.: Геликон Плюс, 2008.

12. Бровцева Н.Л. Историческое сознание как предмет исторического познания: автореф. дис. ... канд. филос. наук. Киров, 2003.

13. Буров В.Ф. Историческое сознание: Опыт философского прочтения. - Абакан: Хакасское книжное издательство, 2004.

14. Леопа А.В. Структура исторического сознания в условиях социокультурного кризиса: автореф. дис. ... канд. филос. наук. - Красноярск, 2004.

15. Мейнеке Ф. Возникновение историзма. - М., 2004.

16. Савельев Ю.Р. Искусство историзма и государственный заказ. Вторая половина XIX - начало XX вв. - М.: Совпадение, 2008.

17. Ельчанинов В.А. Историческое сознание. - Барнаул: Издво Алтайского университета, 2002.

18. Рябов В.В., Хаванов Е.И. Студенчество на рубеже веков: историческое сознание и гражданское становление. - М.: Жизнь и мысль; Московский учебник, 2005.

19. Путятина Т.П. Формирование исторического сознания школьной молодежи в условиях трансформации российского общества: автореф. дис. ... канд. соц. наук. - М., 2007.

20. Марахов В.Г. Социальная философия: курс лекций. - СПб.: Изд-во СПбГУ; ВВМ, 2009.

21. Кутыкова И.В. Тенденции исторического сознания первого постсоветского поколения // Вестник СПбГУ. - 2012. Сер. 12. - Вып. 4.

22. Кутыкова И.В. Проблемный аспект исторического сознания новых поколений. Действительность и возможность в системе отношений «современник-история» / М.Ф. Алиева, Н.А. Бухалова, С.А. Ильиных и др. Современный человек в социальном, духовном и информационном пространстве. M.: Перо, 2012.

23. Копосов Н.Е. Как думают историки. - М.: Новое литературное обозрение, 2001.

24. Харькина А.Г. Проблема исторического континуума мышления в гуманитарном знании: автореф. дис. ... канд. филос. наук. - СПб., 2001.

25. Каграманов Ю.М. «Прошлое страстно глядится в грядущее». Замечания к будущему учебнику истории // Новый мир. 2008. — № 7.

26. Козлов Н.Д. Национальная идея и историческое сознание // Ключ. Альманах Пушкинского центра аналитических исследований и прогнозирования. - Вып. 1. - СПб.: Химиздат, 2009.

27. Петров А.В. Исторические знания в современном обществе: освоение прошлого в войнах памяти // Диалог культур и партнерство цивилизаций: IX Международные Лихачевские научные чтения, 14-15 мая 2009 г. - СПб.: Изд-во СПбГУП, 2009. 
28. Линченко А.А. Целостность исторического сознания (социально-философский аспект): автореф. дис. ... канд. филос. наук. - СПб., 2006.

29. Свирида Н.Н. Историческое сознание как явление культуры: автореф. дис. ... канд. филос. наук. - Омск, 2004.

30. Антипов Г.А. Гносеологические и социокультурные основания исторического знания: автореф. дис. ... д-ра филос. наук. - М., 1995.

31. Леопа А.В. Историческое сознание в условиях социокультурного кризиса. - Красноярск: СФУ, 2011.

32. Историческая память в массовом сознании общества: (Результаты социологического мониторинга): Социология власти // Вестник социологического центра РАГС. - 2003. № 2.
33. Мерзлякова И.Л. Историческое сознание современного российского общества: социально-философский анализ: автореф. дис. ... канд. филос. наук. - Ростов-на-Дону, 2005.

34. Чистанов М.Н. Историческое сознание и социальность. Новосибирск: Новосибирский государственный университет, 2006.

35. Ивенкова О.А. Трансформация повседневного исторического сознания (на материале СССР 1920-1930-х годов): автореф. дис. ... канд. филос. наук. - Смоленск, 2006.

36. Сгибнева О.И. Историческое сознание: сущность, пути формирования: автореф. дис. ... канд. филос. наук. - М., 1991.

37. Каган М.С. Философия культуры. - СПб.: Петрополис, 1996.

38. Маркарян Э.С. Понятие «культура» в системе современных социальных наук. - М.: Наука, 1973.

УДК 749

ББК 85.12

\section{Н.Н. ГОНЧАРОВА}

\section{ПАРНЫЕ ИЗОБРАЖЕНИЯ В РОСПИСИ СЕВЕРНЫХ СУНДУКОВ XVII-XVIII BEKOB}

Рассматривается феномен парных изображений на северорусских сундуках XVII-XVIII веков - одного из наиболее популярных сюжетов в народном искусстве того времени. Молодцы и девицы, дамы и кавалеры в живописных композициях на сундуках, их костюмы, аксессуары и другие детали позволяют проследить переход от древнерусской традиционной одежды к европейскому платью. Ключевые слова: сундук, сюжет, одежда, народное искусство, аксессуары, традиционный костюм, европейское платье, музыкальный инструмент, молодец, девица, кавалер, дама.

C XI века сундуки были в числе основных элементов интерьера традиционного русского дома и сохраняли эту функцию до первой половины XX столетия. Имея практичную и удобную форму, они служили человеку для хранения вещей, для переноски и перевозки домашнего скарба. Сундуки бывали разных форм и размеров, в них держали деньги, документы, книги и разные предметы, необходимые в повседневной жизни.

Лари, ларцы, ларчики, скрыни, подголовки, теремки, погребцы, коробки, укладки, «шкатуны» (шкатулки), футляры и т. п. получили свои названия в разные исторические периоды, но объединены они общим понятием переносного ящика-сундука для хранения ценностей. Отличались эти изделия размером, формой и декором, в их основе всегда был ящик с откидной или отъемной крышкой. В зависимости от величины и формы определялось и назначение сундучного изделия.

Изготовление сундуков - городское ремесло, нуждавшееся в разделении труда. Это было развитое производство, требовавшее владения приемами работы с различными материалами. Сундучники делали деревянные ящики определенных форм, кузнецы занимались их оковкой. В некоторых случаях изделие украшалось росписью, что намного повышало их ценность. Форма, конструкция и декор соответствовали обычаям и отражали региональные особенности.
Среди сохранившихся памятников особое место занимают сундуки с росписью на внутренней поверхности крышек. Подголовки, теремки, скрыни и другие сундучные изделия, при оформлении которых использовалась традиционная система декора, становились отражением мироощущения и эмоционально-психологического склада человека, его имущественной принадлежности, вкуса, общественного положения, идеологической ориентации, свидетельствуя о ценностных приоритетах как владельца, так и мастера, об их тяготении к определенным формам и образам.

Одно из первых упоминаний о расписных сундуках встречается в рукописном сборнике середины XIV века «Мерило праведное». Этот сборник создавался в XIIXIII веках и служил и нравственным наставлением, и юридическим руководством. В одной из статей под названием «0 мирьских людех...» упоминается запрещение помещать «прельщающа писании или на дъскахъ, или на стенахъ, <...> ли на ларцехъ», то есть на сундуках $[1$, с. 219].

Таким образом, осуждались «писании», воспевающие чувственные наслаждения и изображения плотских утех. Подобные сюжеты считались «срамными», ведущими к «страсти разжению», и сурово порицались средневековыми моралистами. Примечательно, что запрет упоминается именно в статье «0 мирьских людех...», то есть речь идет не о церковном искусстве, а о светском, повседневном. То 